\title{
Clinical Manifestations of Cytokine Storm and Immune Response to COVID-19: Literature Review
}

\author{
Saeedeh Kowsarnia \\ Olive View-UCLA Education \& Research Institute, Sylmar, CA, USA \\ Email: skowsarnia@dhs.lacounty.gov
}

How to cite this paper: Kowsarnia, S. (2021) Clinical Manifestations of Cytokine Storm and Immune Response to COVID19: Literature Review. Open Journal of Internal Medicine, 11, 151-174. https://doi.org/10.4236/ojim.2021.113012

Received: July 22, 2021

Accepted: September 4, 2021

Published: September 7, 2021

Copyright $\odot 2021$ by author(s) and Scientific Research Publishing Inc. This work is licensed under the Creative Commons Attribution International License (CC BY 4.0).

http://creativecommons.org/licenses/by/4.0/ (c) (i) Open Access

\begin{abstract}
Spreading COVID-19 disease caused by coronavirus 2 causes tremendous health challenges worldwide. Owing to a high transmission rate, fast-spreading disease, asymptomatic carriers, and high infectivity, we observe a pandemic status that we follow today. Although there are different reports of case fatality rates around the globe, the primary determinant of mortality is age. Symptoms of COVID-19 disease vary from asymptomatic individuals to severe acute respiratory distress syndrome (ARDS) and death. The most common complication of COVID-19 is ARDS. Hyperinflammation due to excessive immune response to coronavirus is the leading cause of severe symptoms seen in the course of COVID-19. The virus enters cells utilizing the S1 subunit through the ACE2 receptor. The innate immune response is the primary immune reaction to virus entry. RNA viruses, including coronavirus, replicate in the cytoplasm, assemble, and then exit by exocytosis. Some suggest that SARS-Cov2 uses cell-cell fusion to infect adjacent cells. Different sensors detect the virus particles in the endosomal compartment and cytoplasm, and infected cells induce an immune response to surrounding cells. As a result, the production of cytokines and chemokines such as interferons (INFs) will be augmented. Since coronavirus uses different means to evade the immune system, it is difficult for immune cells to "sense" them; thus, the coronavirus response is not adequate. It has been showing that even a sufficient level of immunoglobulin response couldn't neutralize virus replication. Therefore, the innate immune response is unable to eradicate SARS-Cov2, causes overexpression of cytokines and chemokines that cannot eliminate the virus. Diminished INFs secretion and apoptosis of regulatory T cells (Treg) are the leading cause of dysregulated immune response in a cytokine storm. Inflammatory cells attack infected and uninfected cells, causing more inflammation
\end{abstract}


and apoptosis of endothelial and epithelial cells. In the end, organ failure occurs due to immune cells' overactivity, cell proliferation, hemorrhage, microthrombi, and remodeling of tissue cells. This review discusses the immune response and pathomechanisms of the associated symptoms in COVID-19.

\section{Keywords}

COVID-19, SARS-Cov 2, Clinical Symptoms, Cytokine Storm, Immunological Manifestation

\section{Introduction}

Coronavirus disease 2019 (COVID-19), caused by severe acute respiratory syndrome coronavirus (SARS-Cov-2), is spreading rapidly, and the number of cases is still rising around the globe. The emerging of this fast-spreading virus became a challenging health problem worldwide due to the high transmission rate and asymptomatic carriers [1] [2]. Presymptomatic virus shedding is another attribute to further raises the transmission rate [3]. Due to the higher affinity to host cells, the novel coronavirus2 has much more infectivity than SARS-Cov-1 [4]. SARSCov-2 transmits by respiratory droplets that may travel $3-6$ feet [5]. COVID19 symptoms range from asymptomatic individuals to severe acute respiratory distress syndrome (ARDS) and death [6]. The major outbreak of severe acute respiratory syndrome by SARS-Cov1 in 2002-2003 had an overall case-fatality rate of 9.6\% [7], and the Middle East respiratory syndrome virus (MERS-Cov) in 2017 had a nearly $36 \%$ mortality rate [8]. Although there are different case fatality rates based on age and countries as the virus reached the pandemic, all studies support increased mortality with higher age [9]. The estimated overall casefatality rate for SARS-Cov- 2 is nearly $6 \%$ in the USA and differs by country [10].

Based on age and baseline comorbidities, COVID-19 symptoms vary, ranging from asymptomatic individuals to severe organ failure and death [11]. The most common complication seen in patients who were admitted to the hospital was ARDS [12]. The way that the immune system responds to coronavirus defines the course and manifestation of COVID-19. A large body of evidence supports that the etiology of tissue damage is immunopathology rather than direct viral invasion. Overexpression of innate immunity in COVID-19 causes tissue destruction and organ failure and are the most common causes of morbidity and mortality. First described in influenza virus infection, hyper inflammation by cytokine storm [13] causes ARDS, distant organ damage, and failure.

There is a growing need for clinicians to understand the pathomechanism and cause of diverse presentations of COVID-19. This review discusses the immune response to coronavirus and how the host response causes clinical manifestations in the novel COVID-19. 


\section{Overview of the Human Immune Response to Coronaviruses}

SARS-CoV-2 is an enveloped, positive-sense, single-stranded, and non-segmented RNA virus with an $80 \%$ genomic composition of SARS-CoV-1 and $96 \%$ bat coronavirus [14].

The new coronavirus (SARS-CoV-2) binds to human epithelial cells by its spike protein (glycoprotein S), recognizes angiotensin-converting enzyme 2 (ACE2) receptor on human cells to initiate the first step of infection [15] [16]. Glycoprotein $S$ has two different subunits: S1 contains receptor binding domain interacting with $\mathrm{ACE} 2$, and $\mathrm{S} 2$, which conveys fusion capabilities to exit endosome into the cytoplasm [15] [17]. Transmembrane proteases of host cells such as transmembrane serine protease 2 (TRMPSS2) activate spike protein and its subunits and enhance coronavirus infectivity [18] [19]. Although ACE2 receptor is expressed in lungs, kidneys, heart, intestine, and testes, well-differentiated nasal epithelia and pneumocytes type 2 serve as the main port of entry and replication of coronavirus in the human body [20] [21] [22] [23] [24].

SARS-Cov-2 has a greater affinity for ACE2 receptors than SARS-Cov-1, although it may enter cells independent of proteases [25]. Furthermore, it has been suggested that SARS-Cov-2 may spread to other cells through cell-cell fusion, explaining the high rate of infectivity and fast-spreading of novel SARSCov-2 [4].

After entering the endosome, SARS-CoV-2 fuses to the endosomal membrane and releases its components into the cytoplasm to start replication [16] [26] [27]. SARS-CoV-2 has two different genes encoding structural and non-structural proteins [23]; a few of these proteins antagonize the antiviral activity of infected cells by coronaviruses [28] [29]. Then, the virus assembles all of its components and exits host cells by exocytosis [26].

The presence of coronavirus in the endosomal complex is sensed by toll-like receptors (TLR). However, in the cytoplasm, virus replication components are recognized by CARDs (caspase activation and recruitment domain). In the presence of the virus, both TLRs and CARDs initiate gene transcriptions of type 1 interferons (IFNs), interleukins IL-1, IL-6, tumor necrosis factor (TNF), and other chemokines [30] [31]. Type 1 INF augments immune response against viruses by stimulating macrophages, natural killer cells, CD8 cells, and B cells [32]. By binding of IFNs to their receptors on the same cells or surrounding cells, antiviral gene transcription is enhanced [30] [33] [34]. In addition, IL-6 has a crucial role in balancing immune response during infection; first, by activating plasma cells, Th17, and follicular helper cells. Second, by blocking CD8 cells and cell-mediated response during cytokine storm [35].

Macrophages and dendritic cells are part of innate immunity and work as antigen-presenting cells (APC). They present antigens to $\mathrm{T}$ cells to promote acquired immunity and produce different immune-modulatory cytokines to differentiate $\mathrm{T}$ cells from various subclasses, such as T-helper 17 [36]. Th17 adjusts 
immune response during infection as well as systemic inflammation. Th17 secretes IL-1, IL-6, IL-8, IL-21, TNF- $\beta$, and monocyte chemoattractant protein (MCP-1) to enhance acquired immunity [37] [38]. CD4 promotes B cells to produce antibodies and regulates immune response, but cytotoxic CD8 clears the body from the virus. CD4 and CD8 are the most abundant lymphocytes reported in the pulmonary interstitial tissue of infected individuals by SARS-Cov. Thus, CD4 and CD8 activation need a balancing act between the eradication of the virus and overwhelming immune response [39] [40] [41]. APCs enhance IL-12 release by $\mathrm{CD} 4$ helper cells that further enhance $\mathrm{CD} 4$ helper maturation and stimulate natural killer cells to eradicate the virus [42].

In the persistent phase of infection, humoral immunity plays an essential role in virus eradication. Although antibodies against envelope protein and spike protein of SARS-Cov1 have a neutralizing effect, COVID-19 replication continues after detectable levels of IgG and Ig-M [40] [43] [44] [45]. The complement system is another integral part of innate immunity activated by SARS-Cov19, leading to clinical symptoms driven by complement activity [46]. Host response to coronaviruses is responsible for the majority of symptoms attributed to coronaviruses [7].

Coronaviruses evade the immune system by different means [47]. The coordinated innate immune response is the first step against viral infections, but excessive and disorganized immune responses may contribute to immunopathology [48]. In addition, the natural immune response tends to act more dysregulated by aging [49]. When the immune system cannot mount the adequate adaptive immune response, a persistent reaction from the innate immune system leads to hyperinflammation states such as cytokine storm, ARDS, and ultimately organ failure [50].

\section{Cytokine Storm}

Cytokine storm is characterized by increased inflammatory markers and multiple organ failure. Infected T cells, and especially CD4, may cause lymphopenia and decrease IFNs production [51]. It has been shown that CD4 numbers may predict viral shedding duration in affected individuals [52]. Infected APCs may cause suboptimal $\mathrm{T}$ cells responses leading to excessive immune responses. In this case, host efforts to clear the virus manifests as an immunopathological lethal disease [53]. Coronavirus infection induces dysregulated responses by a dendritic cell such as low-level expression of antiviral cytokines IFN- $\alpha$ and $\beta$, moderate up-regulation of pro-inflammatory cytokines TNF and IL-6, and a significant up-regulation of inflammatory chemokines C-C ligands like CCL3, CCL5, CCL2, and C-X-C ligand like CXCL10 [54]. Infected macrophages reveal delayed IFN gene induction [55]. Infected airway epithelial cells produce excessive chemokines CCL3, CCL5, CCL2, and CXCL10 [56].

Well-known factors are causing the extreme immune response to coronaviruses. First is coronaviruses' rapid replication. High replication rates and higher 
viral loads enhance the more extensive immune response to infection, manifesting as more severe symptoms [57] [58]. The second is the extension of disease to pneumocytes. Animal studies revealed that immune response to coronavirus is much more extensive when both airway epithelial cells and pneumocytes are infected than when only airway epithelial cells are infected [59]. The third is delayed IFN response due to inhibitory actions of some structural or non-structural proteins encoded by the coronavirus genome. The fast replicating virus hampers INF synthesis, dysregulates monocyte and macrophage response, and subsequently increases T cell apoptosis [48] [51].

Cell destruction is the main aftermath of the extreme immune response. Different studies demonstrate spleen atrophy with necrosis, focal hemorrhages, decreased number of lymphocytes, and increased macrophages' proliferation. The number and size of lymph nodes and the number of CD4 and CD8 in lymphoid tissues may diminish [41] [60]. Due to the accumulation of excessive cytokines, chemokines, and inflammatory cells, apoptosis occurs in endothelial and epithelial cells. INFs and TNF promote apoptosis of tissue cells and compromise microvasculature causing vascular leakage and thrombosis. Organ failure occurs later as tissue damage progress [61] [62]. Another consequence of coronaviruses infection is $\mathrm{T}$ cell apoptosis. Decreased number and function of T cells may significantly impair immunoregulation and virus clearance [63]. As an immune response regulator, CD4 loss causes an increased number of macrophages and phagocytosis in the spleen and lungs [64].

Coronavirus hyper inflammation features are lymphopenia plus increased vital markers such as C-reactive protein (CRP), IL-1 $\beta$, IL-6, IL-2, IL-7, IL-33, TNF $-\alpha$, IFN- $\gamma$, TGF- $\beta$, inducible protein-10 (IP-10), monocyte chemoattractant protein-1 (MCP-1), macrophage inflammatory protein-1 $\alpha$ (MIP-1 $\alpha$ ), chemokines like CCL2, CCL3, CCL5, C-X-C ligand (CXCL8), CXCL9, CXCL10, granulocytecolony stimulating factor (G-CSF), procalcitonin, and ferritin [12] [65] [66] [67] [68]. These cytokines and chemokines increase the production, mobilization, and maturation of inflammatory cells in the infection site [69]. Compared to mild cases, fatal cases had significantly elevated biomarkers [66]. IP-10, MCP-3, and interleukin-1 receptor antagonist (IL-1Ra) were independent predictors for the progression of COVID-19 in severe cases [70]. Clinical characteristic analyses found that cytokine storm highly (increased levels of cytokines IL-1 $\beta$, IL-6, IL-8, IL-10, and TNF $\alpha$ ), lymphopenia (decreased CD4+ and CD8+ T lymphocytes), and decreased IFN $\gamma$ expression in $\mathrm{CD} 4+\mathrm{T}$ cells are associated with severe presentations in COVID-19 [71]. In a retrospective study of 187 COVID-19 patients, IL-6, IL-10, and serum ferritin were strong discriminators for severe disease [72]. Inflammatory marker elevation leads to hyperinflammation and ARDS and increases mortality in extreme cases [69]. Table 1 presents the laboratory results from the articles cited in this review.

\section{Overview of Clinical Manifestations}

Symptoms severity of coronavirus infection depends on airway viral load, age, 
Table 1. Summary of the selected papers cited in this review.

\begin{tabular}{|c|c|}
\hline Author & Results \\
\hline Chen, $\mathrm{N}$ et al. & Neutrophils $\uparrow$, IL-6 $\uparrow, \mathrm{CRP} \uparrow$, Lymph $\downarrow$ \\
\hline $\mathrm{Fu}, \mathrm{L}$ et al. & C.K. $\uparrow$, Procalcitonin $\uparrow, \mathrm{Cr} \uparrow, \mathrm{D}$-dimer $\uparrow, \mathrm{LDH} \uparrow, \mathrm{WBC} \downarrow, \mathrm{Lymph} \downarrow$ \\
\hline Henry, BM et al. & $\begin{array}{l}\mathrm{WBC} \uparrow, \text { Neutrophils } \uparrow, \mathrm{IL}-6 \uparrow, \mathrm{Cr} \uparrow, \mathrm{C} . \mathrm{K} . \uparrow, \mathrm{ESR} \uparrow, \mathrm{CRP} \uparrow, \text { Ferritin } \uparrow, \mathrm{ALT} \uparrow \\
\mathrm{AST} \uparrow, \mathrm{Lymph} \downarrow, \mathrm{Alb} \downarrow\end{array}$ \\
\hline Huang, C et al. & $\begin{array}{l}\text { Neutrophils } \uparrow, \text { Procalcitonin } \uparrow, \mathrm{PT} \uparrow, \mathrm{D} \text {-dimer } \uparrow, \mathrm{LDH} \uparrow, \mathrm{Alb} \downarrow, \mathrm{Lymph} \downarrow \\
\mathrm{WBC} \downarrow\end{array}$ \\
\hline Qin, C et al. & $\begin{array}{l}\text { WBC } \uparrow, \text { Lymph } \downarrow \text {, Procalcitonin } \uparrow, \text { Ferritin } \uparrow, \mathrm{CRP} \uparrow, \mathrm{IL}-2 \mathrm{R} \uparrow, \mathrm{IL}-6 \uparrow, \mathrm{IL}-8 \uparrow \\
\mathrm{IL}-10 \uparrow, \mathrm{CD} 4 \uparrow, \mathrm{B} \text { cell } \uparrow, \mathrm{NK} \text { cell } \uparrow, \text { Naïve cell } \uparrow, \text { memory cells } \uparrow, \mathrm{CD} 28 \uparrow\end{array}$ \\
\hline Wang, D et al. & $\begin{array}{l}\mathrm{WBC} \uparrow, \text { Lymph } \downarrow, \text { Neutrophils } \uparrow, \text { Procalcitonin } \uparrow, \mathrm{LDH} \uparrow, \mathrm{D}-\mathrm{Dimer} \uparrow, \mathrm{C.K} . \uparrow \\
\mathrm{Cr} \uparrow, \mathrm{BUN} \uparrow, \mathrm{AST} \uparrow, \mathrm{ALT} \uparrow\end{array}$ \\
\hline Chen, G et al. & $\begin{array}{l}\mathrm{ALT} \uparrow, \mathrm{LDH} \uparrow, \mathrm{CRP} \uparrow, \text { Ferritin } \uparrow, \mathrm{D} \text {-dimer } \uparrow, \mathrm{IL}-2 \mathrm{R} \uparrow, \mathrm{IL}-6 \uparrow, \mathrm{IL}-10 \uparrow, \mathrm{TNF}-\alpha \uparrow, \\
\mathrm{Lymph} \downarrow, \mathrm{CD} 4+\downarrow, \mathrm{CD} 8+\downarrow\end{array}$ \\
\hline
\end{tabular}

and comorbid conditions [73], although age is the most critical determinant of survival and disease course [9]. Compared to children who have numerous naïve cells ready to respond to new antigens, the number of naïve $\mathrm{T}$ cells diminishes over time in the elderly [74]. In animal models of SARS, aged mice had more expressed cytokine and chemokine responses with lower virus clearance and worse outcomes than young ones [75].

The course of presentation in COVID-19 infected individuals can be divided into three phases: initial infection phase, pulmonary phase, and hyper inflammation phase, including ARDS [76].

Most cases are asymptomatic or mild (81\%). The most common reported symptoms are flu-like illness including fever $(83 \%)$, cough $(82 \%)$, shortness of breath $(31 \%)$, muscle ache $(11 \%)$, confusion $(9 \%)$, headache $(8 \%)$, sore throat (5\%), rhinorrhea (4\%), chest pain (2\%), diarrhea (2\%), and nausea and vomiting (1\%) [6] [77]. The average incubation period from contact to the first symptom was 4 days [78]. In a pooled analysis of 181 COVID-19 patients, the first symptoms presented within 14 days after probable exposure in $99 \%$ of cases [79]. Analysis of 72314 COVID-19 issues from China revealed that $87 \%$ were mild cases defined by no or mild symptoms, $14 \%$ were described as severe with significant lung infiltrates or signs of respiratory compromise, and $5 \%$ were critical cases of respiratory failure, shock, or multiorgan failure [6].

Although a retrospective study of 201 confirmed COVID-19 Chinese patients, 44 individuals $(52.4 \%)$ of $84(41.8 \%)$ patients who suffered from ARDS died (11), another retrospective study of 68 fatal cases, 5 patients (7\%) died from cardiovascular damage, and 22 patients (33\%) died from both respiratory failure and cardiovascular damage [11] [66]. Many studies demonstrated that age and baseline comorbidities are associated with increased risk of severe complications such as ARDS, kidney injury, ICU admission, and death. A vast body of evidence suggests that elevated biomarkers and inflammatory indexes are correlated with increased severity and death rate through the course of disease [11] [12] [80]. A 
severe manifestation usually occurred in 8 - 14 days after the first symptoms, the median time of death within 6 - 19 days after the illness onset, and discharge time was around 3 weeks on average [66] [81] [82] [83]. Figure 1 depicts the immune response to the coronaviruses. The consequences of immunopathologic response showed in red.

\section{Pulmonary Involvement}

We learned from severe acute respiratory syndrome (SARS) that the initial phase of Coronaviridae infection is pulmonary epithelial cell proliferation with innate immune response mediated by macrophages and monocytes [84].

The pulmonary phase proceeds to further lung injury by vasodilation and endothelial permeability due to leukocyte recruitment. Despite diminished viral load, in this phase, hypoxemia and cardiac stress progress further, proportionate to the extent of lung injury [58] [76]. Simultaneous with the decreased viral burden, pulmonary symptoms worsen $1-2$ weeks after initial respiratory symptoms [85].

Diffuse alveolar damage (DAD) is the leading histological feature in lung injury. DAD pathology reveals lung consolidation and edema with pleural effusions and focal hemorrhages with infiltration of neutrophils and macrophages. The viral antigen is detected in vascular and respiratory endothelium, macrophages, lymphocytes, and monocytes [86]. Autopsy of fatal cases revealed fibrin microthrombi and micro infarct [41] [87]. Focal desquamation of alveolar epithelial cells and proliferation of type II pneumocytes were also reported [41]. Prolonged prothrombin time (PT), elevated D-dimer, and activated partial thromboplastin time (APTT) has been reported in hospitalized COVID-19 cases [71] [81] [83]. Despite increased white blood cells and neutrophilia, lymphopenia is a grave sign of disease progression to ARDS in patients with critical conditions [12] [71]. SARS-Cov infection, a virus from the same family of COVID-19 virus, infects lymphocytes and, as a result, decreases both CD4 and CD8 till the end of recovery. T regulatory cells maintain homeostasis of the immune response during infection and recovery to prevent excess immune response, and in SARSCov-2, the number of regulatory and helper T cells is decreased [86] [88] [89]. Older age, hypertension, diabetes, high fever, lymphopenia, injury to other organs, and elevated D-dimer and inflammatory markers are predictors of ARDS. Advanced age, neutropenia, elevated D-dimer, and inflammation is associated with higher mortality in those with ARDS among all risk factors [11].

Soluble ACE 2 in blood has a protective role in heart failure and respiratory failure [90]. Tumor necrosis factor- $\alpha$ convertase (ADAM17) has cleavage activity on ACE 2 receptors and releases soluble ACE 2 [91]. Administration of soluble ACE 2 had a favorable result in ARDS and lung injury [90] [92]. It's still unclear if the use of ADAMS17 could be protective against viral entry in ARDS associated with SARS-Cov 2. However, a new study reported that recombinant Human ACE 2 (hrsACE2) could significantly block early SARS-CoV-2 infections on engineered human cells infected by SARS-Cov 2 [93]. 


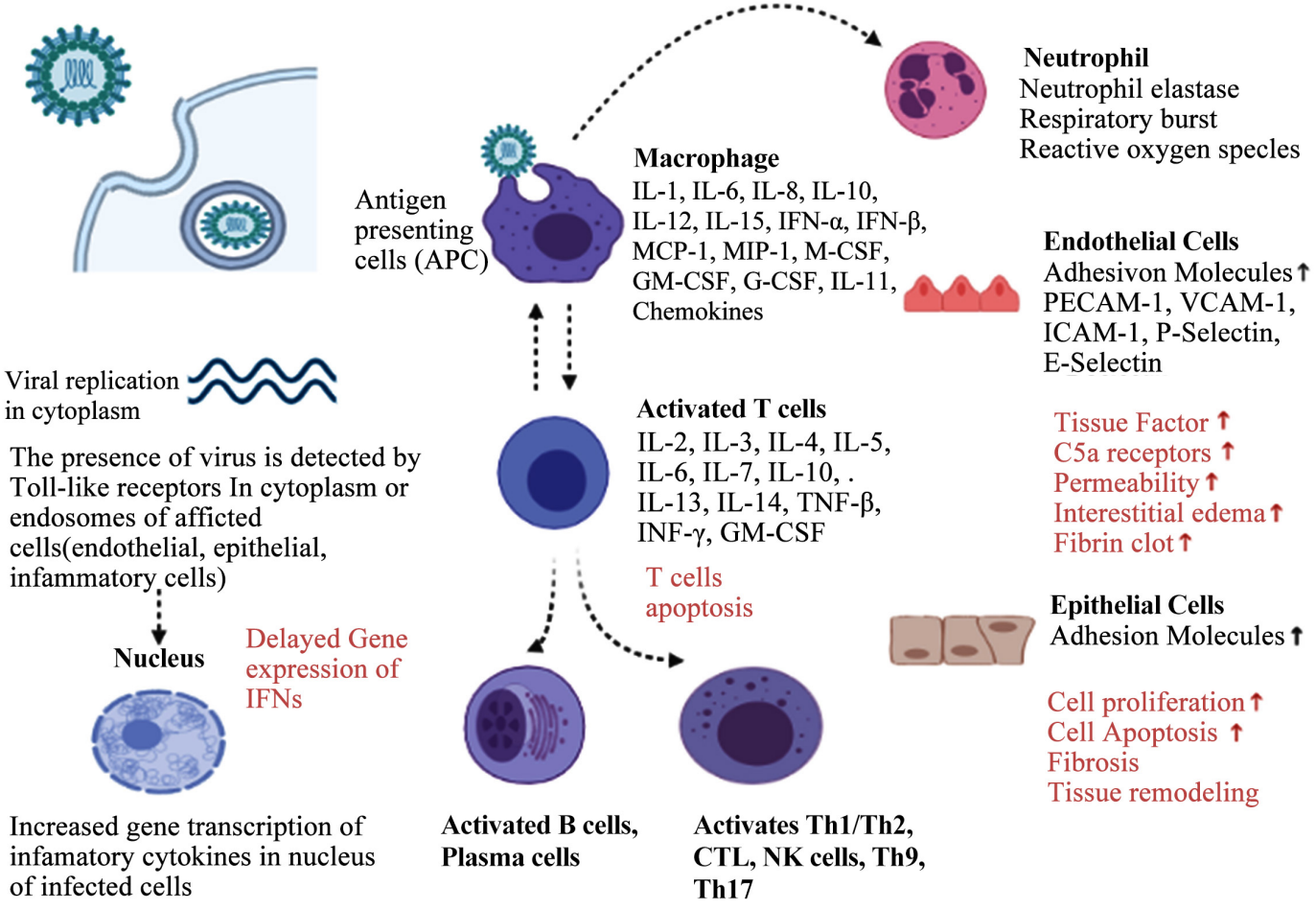

Figure 1. Consequences of extreme immune response to coronaviruses. Created with BioRender.com.

Despite diminishing viral loads, some patients may suffer from distant organ injury with excessive immune response. Distant Organ injury without virus infiltration shows the role of Systemic inflammation in distant organ failure [41].

\section{Radiologic Findings}

Bilateral pulmonary infiltrations were more common than unilateral infiltration (95\% vs. 5\%) [11]. Bilateral reticulonodular opacities (52.4\%), ground-glass opacities (47.6\%), pleural effusion (28.6\%), peribronchial thickening (23.8\%), focal consolidation (19\%), pulmonary edema (9.5\%), venous congestion (4.8\%), atelectasis (4.8\%), and clear chest $\mathrm{x}$-ray (4.8\%) [94] are the most common findings in patients who were admitted due to COVID-19. Ground-glass opacities (80.0\%) and bilateral pneumonia (73.2\%) were the most common findings on chest CT scans [78].

\section{Cardiovascular Involvement}

The rate of cardiac injury among different studies was variable from $7 \%$ to $18 \%$ in hospitalized cases [12] [81] [82] [83]. Cardiac injury is the independent risk of mortality along with lung injury [82]. Mortality was $51.2 \%$ in cases with cardiac injury versus $4.5 \%$ of patients without cardiac injury [82]. Initial cardiac injury with elevated troponin has been reported with no lung injury [95] [96]. COVID19 associated heart failure was $23 \%$ among all the patients and 58\% among fatal cases [83]. ACE 2 receptor, the port of entry for SARS-Cov 2, basically regulates heart function, and in an animal study, mice with dysfunctional ACE 2 receptors 
developed left ventricular failure [97]. SARS-Cov infection downregulates heart ACE 2 receptors, theoretically enhancing heart dysfunction [98]. Severe cases of COVID-19 had a higher level of troponin I and brain natriuretic peptide (BNP) [66] [94]. Equally important, there is a correlation between cardiac enzyme levels and prognosis and mortality rate in patients with SARS-Cov 2 infection [83]. Among all mortality factors in COVID 19 patients, cardiac injury has a more significant weight [81] [82].

The cardiac injury mechanism is not precise, but a combination of direct viral infiltration, systemic inflammation, hypoxia, and cardiac stress is plausible. Like SARS-Cov1, SARS-Cov 2 viral inclusions have been seen in the myocardium and cardiac vasculature [98] [99]. Animal studies show that IL-6 and TNF can cause systolic dysfunction [100] [101]. Mitochondrial dysfunction may lead to cardiac dysfunction in septicemia [102]. Cleavage of ACE 2 receptors by TNF $\alpha$ convertase (ADAMS-17) may decrease local membrane ACE 2 and play a protective role against the virus entry. Soluble ACE 2 may diminish ACE 2 receptors and reduce the risk of heart dysfunction, although it may act as a compensatory mechanism in heart failure [103] [104]. Pericytes have the highest number of ACE 2 receptors in the heart, and their dysfunction disrupts microcirculation, causing ischemia [105]. ACE 2 interacts with inflammatory cells, including macrophages, to reduce inflammation; thus, lower angiotensin 2 levels have pro-inflammatory effects [106] [107]. Study shows that macrophages and CD4 cells myocardial infiltration in SARS-Cov1 were detected in 35\% human heart autopsy samples [98]. The significant risk factors associated with elevated troponin are age, male gender, and associated comorbidities such as hypertension. In addition, elevated troponin was associated with an increased risk of ARDS, kidney injury arrhythmia, and coagulopathy [81].

Blood pressure and heart rhythm abnormalities are frequently seen in critically ill SARS-Cov 2 patients. However, it's not clear whether blood pressure changes are due to ACE 2 receptor or vagoplegic status in critically ill patients [66] [71].

Although one study shows different arrhythmias from tachycardia and bradycardia to asystole is prevalent in $16.7 \%-44.4 \%$ of severe ICU cases [12], another study reported 5.9\% ventricular tachycardia and fibrillation [81]. In addition, patients with pneumonia have a higher risk of cardiovascular events [108]. Presumably, acute myocardial events risk factors in COVID-19 patients are platelet, endothelial cells, and macrophage activation associated with hyperinflammation.

A systemic infection such as influenza may activate the immune system and inflammatory cytokine cascade. Study shows that local arterial inflammation may activate inflammatory cells in atheroma, leading to plaque rupture [109] [110]. Vasoconstriction may also occur with the activation of vascular endothelial cells due to inflammation [111]. The D-Dimer level was significantly increased in COVID-19 cases, showing that hypercoagulability state may lead to myocardial injury or vasculature thrombosis [112]. 


\section{Renal Involvement}

Overall, 40\% of COVID-19 cases have abnormal kidney function [80], and kidney injury may occur in $0.5 \%$ to $15 \%$ of cases. Both virus proliferation and hyper inflammation may contribute to kidney injury of COVID-19 patients [80]. Kidney injury incidence was significantly higher in males, older patients with comorbidities such as hypertension and chronic kidney disease. Fatal hospitalized cases had a significantly higher rate of kidney injury that is more common in $\mathrm{Pa}$ tients with higher leukocyte count and procalcitonin levels (69). Although the urinary system, including the kidney, has a very high ACE 2 receptor expression, microscopic examination of SARS patients did not show any electron-dense deposits [113] [114]. However, in COVID-19 patients with nephropathies, SARScov2 induced cytoplasmic renal tubular inclusions [115]. Cytokine storm and systemic inflammatory response cause endothelial dysfunction and thrombosis, causing microangiopathies [116]. Injured renal tubular cells upregulated the IL-6 that has a key role in cytokine storm [11]. Since COVID-19 patients have increased creatinine kinase due to hypoxia and shock, thus rhabdomyolysis may contribute to kidney injury [12].

\section{Hepatic Involvement}

The elevated liver enzyme was a common finding in nearly $21 \%$ - 37\% of COVID19 cases [6] [83], and liver failure defined as high liver enzyme $>3$ times of standard limit reported in 48\% - 62\% fatal cases [94]. Although ACE 2 receptors present in cholangiocytes, they do not exist on hepatocytes, Kupffer cells, and endothelial cells [117]. Because of the average level of alkaline phosphates in COVID-19 patients, there should be another mechanism for liver injury by SARSCov 2. Hypoxemia and shock are the possible liver injury etiologies in COVID19 patients [118]. Studies showed the correlation between Lymphopenia and C-reactive protein and liver injury in patients with COVID-19 [119]. In addition, viral RNA was detected in the liver in post mortem studies showing mild lobular lymphocytic infiltration with focal macrovesicular steatosis and mild sinusoidal dilatation [120].

\section{Thrombosis}

Systemic infection may be complicated with coagulation dysfunction mediated by cytokines leading to multiple organ failure [121]. Inflammatory cytokines such as TNF- $\alpha$, IL- $1 \alpha$, IL- $1 \beta$, IL- 6 , IL- 8 , leukemia inhibitory factor, IFN- $\gamma$, and monocyte chemoattractant protein 1 (MCP-1) in addition to endothelial injury, activate tissue factor and enhance prothrombotic state [122] [123] [124]. Infection may activate platelets, enhancing coagulation [125]. Post mortem reports of fatal cases of ARDS due to SARS-Cov 1 revealed pulmonary vascular thrombosis [99]. IL- $1 \beta$ and IL-6 promote the expression of adhesion molecules on endothelial cells leading to inflammatory cell infiltration and vascular inflammation. Indeed, cellular damage and local viral proliferation enhance endothelial dys- 
function and microthrombi further [126] [127]. The localized macrophages can also release pro-coagulant factors such as plasminogen activators, secreted by macrophages angiotensin II, enhancing a prothrombotic state manifested by the microthrombi formation in several organs.

\section{Nervous System Involvement}

Several studies reported neurologic involvement by coronaviruses. Coronaviruses infected the brain could cause polyneuropathy, encephalitis, and ischemic stroke [128]. Infection-induced encephalopathy may present as cerebral edema without evidence of inflammation in cerebrospinal fluid analysis. Patients may develop headaches, dysphoria, mental illnesses, and delirium. Disorientation, loss of consciousness, coma, and paralysis may occur in severe cases [129]. Nearly $20 \%$ of patients infected by MERS-Cov exhibited neurologic complications that appeared approximately 2 - 3 weeks after resolving respiratory symptoms. Ranging from neuropathies to encephalitis, symptoms varied from hyperesthesia, toxic and infectious neuropathies, intensive-care-unit-acquired weakness, and Bickerstaff's encephalitis overlapping with Guillain-Barré syndrome [130]. As well in Post-mortem reports of SARS-CoV cases, infiltration of monocytes and lymphocytes in the vessels, demyelination of nerve fibers, ischemic changes of neurons, and virus particles were noted [86]. Brain Biopsy of Patients with multiple sclerosis(MS) showed that Human coronaHCOV viruses particles in tissues [131] [132]. Nearly 50\% of patients with MS had RNA of HcoV-Oc43 in their CSF [133]. It appeared that activated $\mathrm{T}$ cells in These patients were hyper-reactive to myelin as well as the virus 16 . Few patients have new reports of Miller Fisher syndrome, a variant of Guillain-Barré syndrome, and polyneuritis cranialis in COVID-19 patients [134]. About 36.5\% of COVID-19 patients may develop neurological symptoms and more commonly seen in patients with severe symptoms. Both central and peripheral nervous systems may be involved. Headache, paresthesia, loss of consciousness, hypogeusia, anosmia, and seizures are among the most prevalent symptoms [135]. Approximately $33.9 \%$ of Patients with CoVID-19 reported olfactory or taste involvement, with $18.6 \%$ reported both [136]. Studies defined coronaviruses probably gaining access to the CNS by At least 3 routes, including the olfactory nerve, a hematogenous route, and lymphatic systems [137] [138]. Infected macrophages circulating in the blood throughout the body may contribute to direct nervous system invasion. Coronaviruses infect macrophages, microglia, and astrocytes in CNS and infected. Glial cells may secrete numerous inflammatory cytokines such as IL-6, IL-12, IL-15, and TNF- $\alpha$ [139]. CNS infection with SARS-CoV 2 activates CD4+, which induces the macrophages to secrete interleukin-6 (IL6) [140]. Sparse perivascular and leptomeningeal infiltrates of CD3 + T lymphocytes in COVID-19 brains, similarly encountered in sepsis or systemic inflammation [140]. Increased permeability of the blood-brain barrier by hyperinflammation facilitating more cytokines entry and viral invasion is another possibility [141] [142]. SARS-Cov in- 
volves Brain tissue through attachment to the endothelial lining of the bloodbrain barrier and brain vessels. SARS-Cov enters the brain cells by virus budding during replication as well 50. Vascular Endothelial damage by viral replication results in vascular rupture and may cause cerebral hemorrhage and death seen in a patient with COVID-19 [143] [144] [145]. The olfactory nerve has been suggested as one of the neuronal portal entries of respiratory viruses, including coronaviruses [145] [146]. Direct Viral entry to the nervous system occurs through the cribriform plate or olfactory bulb by trans-synaptic route [138] [147] [148] [149]. There are reports of encephalitis with detection of viral RNA in cerebrospinal fluid with the possibility of direct central nervous system invasion by SARS-Cov2 [150] [151]. Post mortem studies of COVID-19 cases showed lymphocytic endotheliitis (endothelialitis) in vessels and Lymphatic drainage of in internal organs such as heart, kidney, lung, liver, the small intestine and brain. Endothelialitis causes vascular dysfunction that leads to organ ischemia, tissue edema, and a prothrombic state due to vasoconstriction and associated inflammation [152] [153].

Mice infected with SARS-Cov had brain involvement that was more prominent in the brain stem and thalamus area, cardiopulmonary regulation, and it may play a role in cardiopulmonary compromise in COVID-19 patients [154] [155]. SARS-Cov downregulates replication of ACE protein in infected cells of organs like the brain. Decreased level of ACE leads to the insensitivity of baroreceptors and fluctuation of heart rates and blood pressure and, in addition to sympathetic overactivity, result in blood pressure elevation and cardiac dysfunction [156].

Another cause of brain damage in patients with COVID-19 is toxic encephalopathy caused by Severe hypoxia and viremia [137]. Subsequent brain injury ensues with further hypoxemia, which causes brain edema and intracranial hypertension with deterioration of brain function [157]. Cytokine storm during lung injury, hypoxemia, and sympathetic overactivity leads to CNS hyperactivity which might play a crucial role in the pathogenesis of neurogenic pulmonary edema (NPE), result of neurologic insult, and which finally deteriorate respiratory and cardiovascular function in COVID-19 patients [158] [159].

Increased D-dimer and platelet has been reported frequently in a cytokine storm, showing the propensity to hypercoagulation and cerebrovascular accident in COVID-19 [94] [160]. Nearly 5\% of COVID-19 patients developed signs of cerebrovascular accidents, which was more common in patients with older age, cardiovascular risk factors, and higher C-reactive protein and D-dimer [135] [161].

\section{Conclusion}

Inadequate adaptive immune response leads to immune dysregulation, destroying infected and uninfected cells. Hyper inflammation and apoptosis of endothelial and epithelial cells lead to organ failure due to immune cells' overactivity. 
Cell proliferation, hemorrhage, microthrombi, and tissue remodeling are all consequent, making the symptoms we onlbserve with SARS-Cov 2 infection.

\section{Conflicts of Interest}

The author declares no conflicts of interest regarding the publication of this paper.

\section{References}

[1] Rothe, C., Schunk, M., Sothmann, P., Bretzel, G., Froeschl, G., Wallrauch, C., et al. (2020) Transmission of 2019-nCoV Infection from an Asymptomatic Contact in Germany. New England Journal, 382, 970-971.

https://doi.org/10.1056/NEJMc2001468

[2] Callaway, E., Cyranoski, D., Mallapaty, S., Stoye, E. and Tollefson, J. (2020) The Coronavirus Pandemic in Five Powerful Charts. Nature, 579, 482-483. https://doi.org/10.1038/d41586-020-00758-2

[3] Del Pozo, V., De Andres, B., Martin, E., Maruri, N., Zubeldia, J.M., Palomino, P., et al. (1990) Murine Eosinophils and IL-1: Alpha IL-1 mRNA Detection by in Situ Hybridization. Production and Release of IL-1 from Peritoneal Eosinophils. Journal of Immunology, 144, 3117-3122.

[4] Ou, X., Liu, Y., Lei, X., Li, P., Mi, D., Ren, L., et al. (2020) Characterization of Spike Glycoprotein of SARS-CoV-2 on Virus Entry and Its Immune Cross-Reactivity with SARS-CoV. Nature Communications, 11, Article No. 1620. https://doi.org/10.1038/s41467-020-15562-9

[5] van Doremalen, N., Bushmaker, T., Morris, D.H., Holbrook, M.G., Gamble, A., Williamson, B.N., et al. (2020) Aerosol and Surface Stability of SARS-CoV-2 as Compared with SARS-CoV-1. New England Journal, 382, 1564-1567.

https://doi.org/10.1056/NEJMc2004973

[6] Wu, Z. and McGoogan, J.M. (2020) Characteristics of and Important Lessons from the Coronavirus Disease 2019 (COVID-19) Outbreak in China: Summary of a Report of 72314 Cases from the Chinese Center for Disease Control and Prevention. $J A M A, 323,1239-1242$. https://doi.org/10.1001/jama.2020.2648

[7] Perlman, S. and Dandekar, A.A. (2005) Immunopathogenesis of Coronavirus Infections: Implications for SARS. Nature Reviews Immunology, 5, 917-927.

https://doi.org/10.1038/nri1732

[8] Senga, M., Arabi, Y.M. and Fowler, R.A. (2017) Clinical Spectrum of the Middle East Respiratory Syndrome Coronavirus (MERS-CoV). Journal of Infection and Public Health, 10, 191-194. https://doi.org/10.1016/j.jiph.2016.04.008

[9] Onder, G., Rezza, G. and Brusaferro, S. (2020) Case-Fatality Rate and Characteristics of Patients Dying in Relation to COVID-19 in Italy. JAMA, 232, 1775-1776.

https://doi.org/10.1001/jama.2020.4683

[10] Center JHCR (2020) Mortality Analyses. https://coronavirus.jhu.edu/data/mortality

[11] Wu, C., Chen, X., Cai, Y., Xia, J., Zhou, X., Xu, S., et al. (2020) Risk Factors Associated with Acute Respiratory Distress Syndrome and Death in Patients with Coronavirus Disease 2019 Pneumonia in Wuhan, China. JAMA Internal Medicine, 180, 934-943. https://doi.org/10.1001/jamainternmed.2020.0994

[12] Wang, D., Hu, B., Hu, C., Zhu, F., Liu, X., Zhang, J., et al. (2020) Clinical Characte- 
ristics of 138 Hospitalized Patients with 2019 Novel Coronavirus-Infected Pneumonia in Wuhan, China. JAMA, 323, 1061-1069.

https://doi.org/10.1001/jama.2020.1585

[13] Zeng, H., Belser, J.A., Goldsmith, C.S., Gustin, K.M., Veguilla, V., Katz, J.M., et al. (2015) A(H7N9) Virus Results in Early Induction of Proinflammatory Cytokine Responses in Both Human Lung Epithelial and Endothelial Cells and Shows Increased Human Adaptation Compared with Avian H5N1 Virus. Journal of Virology, 89, 4655-4667. https://doi.org/10.1128/JVI.03095-14

[14] Zhou, P., Yang, X.L., Wang, X.G., Hu, B., Zhang, L., Zhang, W., et al. (2020) A Pneumonia Outbreak Associated with a New Coronavirus of Probable Bat Origin. Nature, 579, 270-273. https://doi.org/10.1038/s41586-020-2012-7

[15] Yan, R., Zhang, Y., Li, Y., Xia, L., Guo, Y. and Zhou, Q. (2020) Structural Basis for the Recognition of SARS-CoV-2 by Full-Length Human ACE2. Science, 367, 14441448. https://doi.org/10.1126/science.abb2762

[16] Hoffmann, M., Kleine-Weber, H., Schroeder, S., Kruger, N., Herrler, T., Erichsen, S., et al. (2020) SARS-CoV-2 Cell Entry Depends on ACE2 and TMPRSS2 and Is Blocked by a Clinically Proven Protease Inhibitor. Cell, 181, 271-280.e8. https://doi.org/10.1016/j.cell.2020.02.052

[17] Belouzard, S., Chu, V.C. and Whittaker, G.R. (2009) Activation of the SARS Coronavirus Spike Protein via Sequential Proteolytic Cleavage at Two Distinct Sites. Proceedings of the National Academy of Sciences of the United States of America, 106, 5871-5876. https://doi.org/10.1073/pnas.0809524106

[18] Millet, J.K. and Whittaker, G.R. (2015) Host Cell Proteases: Critical Determinants of Coronavirus Tropism and Pathogenesis. Virus Research, 202, 120-134.

https://doi.org/10.1016/j.virusres.2014.11.021

[19] Simmons, G., Zmora, P., Gierer, S., Heurich, A. and Pohlmann, S. (2013) Proteolytic Activation of the SARS-Coronavirus Spike Protein: Cutting Enzymes at the Cutting Edge of Antiviral Research. Antiviral Research, 100, 605-614. https://doi.org/10.1016/j.antiviral.2013.09.028

[20] Jia, H.P., Look, D.C., Shi, L., Hickey, M., Pewe, L., Netland, J., et al. (2005) ACE2 Receptor Expression and Severe Acute Respiratory Syndrome Coronavirus Infection Depend on Differentiation of Human Airway Epithelia. Journal of Virology, 79, 14614-14621. https://doi.org/10.1128/JVI.79.23.14614-14621.2005

[21] Zhao, Y., Zhao, Z., Wang, Y., Zhou, Y., Ma, Y. and Zuo, W. (2020) Single-Cell RNA Expression Profiling of ACE2, the Receptor of SARS-CoV-2. American Journal of Respiratory and Critical Care Medicine, 203, 756-759. https://doi.org/10.1164/rccm.202001-0179le

[22] Wang, Z. and $\mathrm{Xu}, \mathrm{X}$. (2020) scRNA-seq Profiling of Human Testes Reveals the Presence of the ACE2 Receptor, A Target for SARS-CoV-2 Infection in Spermatogonia, Leydig and Sertoli Cells. Cells, 9, Article No. 920.

https://doi.org/10.3390/cells9040920

[23] Fehr, A.R. and Perlman, S. (2015) Coronaviruses: An Overview of Their Replication and Pathogenesis. In: Maier, H., Bickerton, E. and Britton, P., Eds., Coronaviruses, Vol. 1282, Humana Press, New York, 1-23.

https://doi.org/10.1007/978-1-4939-2438-7 1

[24] Sungnak, W., Huang, N., Becavin, C., Berg, M., Queen, R., Litvinukova, M., et al. (2020) SARS-CoV-2 Entry Factors Are Highly Expressed in Nasal Epithelial Cells Together with Innate Immune Genes. Nature Medicine, 26, 681-687. https://doi.org/10.1038/s41591-020-0868-6 
[25] Wrapp, D., Wang, N., Corbett, K.S., Goldsmith, J.A., Hsieh, C.L., Abiona, O., et al. (2020) Cryo-EM Structure of the 2019-nCoV Spike in the Prefusion Conformation. Science, 367, 1260-1263. https://doi.org/10.1126/science.abb2507

[26] Siu, Y.L., Teoh, K.T., Lo, J., Chan, C.M., Kien, F., Escriou, N., et al. (2008) The M, E, and N Structural Proteins of the Severe Acute Respiratory Syndrome Coronavirus Are Required for Efficient Assembly, Trafficking, and Release of Virus-Like Particles. Journal of Virology, 82, 11318-11330. https://doi.org/10.1128/JVI.01052-08

[27] Xia, S., Zhu, Y., Liu, M., Lan, Q., Xu, W., Wu, Y., Ying, T., Liu, S., Shi, Z., Jiang, S. and Lu, L. (2020) Fusion Mechanism of 2019-nCoV and Fusion Inhibitors Targeting HR1 Domain in Spike Protein. Cellular \& Molecular Immunology, 17, 765-767. https://doi.org/10.1038/s41423-020-0374-2

[28] Frieman, M., Yount, B., Heise, M., Kopecky-Bromberg, S.A., Palese, P. and Baric, R.S. (2007) Severe Acute Respiratory Syndrome Coronavirus ORF6 Antagonizes STAT1 Function by Sequestering Nuclear Import Factors on the Rough Endoplasmic Reticulum/Golgi Membrane. Journal of Virology, 81, 9812-9824. https://doi.org/10.1128/JVI.01012-07

[29] Siu, K.L., Chan, C.P., Kok, K.H., Chiu-Yat Woo, P. and Jin, D.Y. (2014) Suppression of Innate Antiviral Response by Severe Acute Respiratory Syndrome Coronavirus M Protein Is Mediated through the First Transmembrane Domain. Cellular \& Molecular Immunology, 11, 141-149. https://doi.org/10.1038/cmi.2013.61

[30] Akira, S., Uematsu, S. and Takeuchi, O. (2006) Pathogen Recognition and Innate Immunity. Cell, 124, 783-801. https://doi.org/10.1016/j.cell.2006.02.015

[31] Ivashkiv, L.B. and Donlin, L.T. (2014) Regulation of Type I Interferon Responses. Nature Reviews Immunology, 14, 36-49. https://doi.org/10.1038/nri3581

[32] Diebold, S.S., Montoya, M., Unger, H., Alexopoulou, L., Roy, P., Haswell, L.E., et al. (2003) Viral Infection Switches Non-Plasmacytoid Dendritic Cells into High Interferon Producers. Nature, 424, 324-328. https://doi.org/10.1038/nature01783

[33] Frieman, M., Heise, M. and Baric, R. (2008) SARS Coronavirus and Innate Immunity. Virus Research, 133, 101-112. https://doi.org/10.1016/j.virusres.2007.03.015

[34] Schneider, W.M., Chevillotte, M.D. and Rice, C.M. (2014) Interferon-Stimulated Genes: A Complex Web of Host Defenses. Annual Review of Immunology, 32, 513-545. https://doi.org/10.1146/annurev-immunol-032713-120231

[35] Velazquez-Salinas, L., Verdugo-Rodriguez, A., Rodriguez, L.L. and Borca, M.V. (2019) The Role of Interleukin 6 during Viral Infections. Frontiers in Microbiology, 10, Article No. 1057. https://doi.org/10.3389/fmicb.2019.01057

[36] Wu, L. and Dakic, A. (2004) Development of Dendritic Cell System. Cellular \& Molecular Immunology, 1, 112-118.

[37] Manni, M.L., Robinson, K.M. and Alcorn, J.F. (2014) A Tale of Two Cytokines: IL-17 and IL-22 in Asthma and Infection. Expert Review of Respiratory Medicine, 8, 25-42. https://doi.org/10.1586/17476348.2014.854167

[38] Bunte, K. and Beikler, T. (2019) Th17 Cells and the IL-23/IL-17 Axis in the Pathogenesis of Periodontitis and Immune-Mediated Inflammatory Diseases. International Journal of Molecular Sciences, 20, Article No. 3394. https://doi.org/10.3390/ijms20143394

[39] Channappanavar, R., Fett, C., Zhao, J., Meyerholz, D.K. and Perlman, S. (2014) Virus-Specific Memory CD8 T Cells Provide Substantial Protection from Lethal Severe Acute Respiratory Syndrome Coronavirus Infection. Journal of Virology, 88, 11034-11044. https://doi.org/10.1128/JVI.01505-14

[40] Pascal, K.E., Coleman, C.M., Mujica, A.O., Kamat, V., Badithe, A., Fairhurst, J., et 
al. (2015) Pre- and Postexposure Efficacy of Fully Human Antibodies against Spike Protein in a Novel Humanized Mouse Model of MERS-CoV Infection. Proceedings of the National Academy of Sciences of the United States of America, 112, 87388743. https://doi.org/10.1073/pnas.1510830112

[41] Yao, X.H., Li, T.Y., He, Z.C., Ping, Y.F., Liu, H.W., Yu, S.C., et al. (2020) A Pathological Report of Three COVID-19 Cases by Minimally Invasive Autopsies. Zhonghua Bing Li Xue Za Zhi, 49, E009.

[42] Rabi, F.A., Al Zoubi, M.S., Kasasbeh, G.A., Salameh, D.M. and Al-Nasser, A.D. (2020) SARS-CoV-2 and Coronavirus Disease 2019: What We Know So Far. Pathogens, 9, Article No. 231. https://doi.org/10.3390/pathogens9030231

[43] Wolfel, R., Corman, V.M., Guggemos, W., Seilmaier, M., Zange, S., Muller, M.A., et al. (2020) Author Correction: Virological Assessment of Hospitalized Patients with COVID-2019. Nature, 588, E35. https://doi.org/10.1038/s41586-020-2984-3

[44] Coleman, C.M., Liu, Y.V., Mu, H., Taylor, J.K., Massare, M., Flyer, D.C., et al. (2014) Purified Coronavirus Spike Protein Nanoparticles Induce Coronavirus Neutralizing Antibodies in Mice. Vaccine, 32, 3169-3174.

https://doi.org/10.1016/j.vaccine.2014.04.016

[45] Chen, W., Xu, Z., Mu, J., Yang, L., Gan, H., Mu, F., et al. (2004) Antibody Response and Viraemia during the Course of Severe Acute Respiratory Syndrome (SARS)Associated Coronavirus Infection. Journal of Medical Microbiology, 53, 435-438. https://doi.org/10.1099/jmm.0.45561-0

[46] Gralinski, L.E., Sheahan, T.P., Morrison, T.E., Menachery, V.D., Jensen, K., Leist, S.R., et al. (2018) Complement Activation Contributes to Severe Acute Respiratory Syndrome Coronavirus Pathogenesis. mBio, 9, e01753-18.

https://doi.org/10.1128/mBio.01753-18

[47] Astuti, I. and Ysrafil (2020) Severe Acute Respiratory Syndrome Coronavirus 2 (SARS-CoV-2): An Overview of Viral Structure and Host Response. Diabetes \& $\mathrm{Me}-$ tabolic Syndrome, 14, 407-412. https://doi.org/10.1016/j.dsx.2020.04.020

[48] Channappanavar, R., Fehr, A.R., Vijay, R., Mack, M., Zhao, J., Meyerholz, D.K., et al. (2016) Dysregulated Type I Interferon and Inflammatory Monocyte-Macrophage Responses Cause Lethal Pneumonia in SARS-CoV-Infected Mice. Cell Host Microbe, 19, 181-193. https://doi.org/10.1016/j.chom.2016.01.007

[49] Shaw, A.C., Goldstein, D.R. and Montgomery, R.R. (2013) Age-Dependent Dysregulation of Innate Immunity. Nature Reviews Immunology, 13, 875-887. https://doi.org/10.1038/nri3547

[50] Teijaro, J.R., Walsh, K.B., Rice, S., Rosen, H. and Oldstone, M.B. (2014) Mapping the Innate Signaling Cascade Essential for Cytokine Storm during Influenza Virus infection. Proceedings of the National Academy of Sciences of the United States of America, 111, 3799-804. https://doi.org/10.1073/pnas.1400593111

[51] Chen, G., Wu, D., Guo, W., Cao, Y., Huang, D., Wang, H., et al. (2020) Clinical and Immunological Features of Severe and Moderate Coronavirus Disease 2019. Journal of Clinical Investigation, 130, 2620-2629.

[52] Ling, Y., Xu, S.B., Lin, Y.X., Tian, D., Zhu, Z.Q., Dai, F.H., et al. (2020) Persistence and Clearance of Viral RNA in 2019 Novel Coronavirus Disease Rehabilitation Patients. Chinese Medical Journal, 133, 1039-1043. https://doi.org/10.1097/CM9.0000000000000774

[53] de Groot-Mijnes, J.D., van Dun, J.M., van der Most, R.G. and de Groot, R.J. (2005) Natural History of a Recurrent Feline Coronavirus Infection and the Role of Cellular Immunity in Survival and Disease. Journal of Virology, 79, 1036-1044. 
https://doi.org/10.1128/JVI.79.2.1036-1044.2005

[54] Cheung, C.Y., Poon, L.L., Ng, I.H., Luk, W., Sia, S.F., Wu, M.H., et al. (2005) Cytokine Responses in Severe Acute Respiratory Syndrome Coronavirus-Infected Macrophages in Vitro: Possible Relevance to Pathogenesis. Journal of Virology, 79, 7819-7826. https://doi.org/10.1128/JVI.79.12.7819-7826.2005

[55] Law, H.K., Cheung, C.Y., Ng, H.Y., Sia, S.F., Chan, Y.O., Luk, W., et al. (2005) Chemokine Up-Regulation in SARS-Coronavirus-Infected, Monocyte-Derived Human Dendritic Cells. Blood, 106, 2366-2374. https://doi.org/10.1182/blood-2004-10-4166

[56] Yen, Y.T., Liao, F., Hsiao, C.H., Kao, C.L., Chen, Y.C. and Wu-Hsieh, B.A. (2006) Modeling the Early Events of Severe Acute Respiratory Syndrome Coronavirus Infection in Vitro. Journal of Virology, 80, 2684-2693. https://doi.org/10.1128/JVI.80.6.2684-2693.2006

[57] Chu, C.M., Poon, L.L., Cheng, V.C., Chan, K.S., Hung, I.F., Wong, M.M., et al. (2004) Initial Viral Load and the Outcomes of SARS. Canadian Medical Association Journal, 171, 1349-1352. https://doi.org/10.1503/cmaj.1040398

[58] Peiris, J.S., Chu, C.M., Cheng, V.C., Chan, K.S., Hung, I.F., Poon, L.L., et al. (2003) Clinical Progression and Viral Load in a Community Outbreak of Coronavirus-Associated SARS Pneumonia: A Prospective Study. Lancet, 361, 1767-1772. https://doi.org/10.1016/S0140-6736(03)13412-5

[59] Roberts, A., Deming, D., Paddock, C.D., Cheng, A., Yount, B., Vogel, L., et al. (2007) A Mouse-Adapted SARS-Coronavirus Causes Disease and Mortality in BALB/c Mice. PLoS Pathogens, 3, e5. https://doi.org/10.1371/journal.ppat.0030005

[60] Zhang, T., Sun, L.X. and Feng, R.E. (2020) Comparison of Clinical and Pathological Features between Severe Acute Respiratory Syndrome and Coronavirus Disease 2019. Chinese Journal of Tuberculosis and Respiratory Diseases, 43, E040.

[61] Herold, S., Steinmueller, M., von Wulffen, W., Cakarova, L., Pinto, R., Pleschka, S., et al. (2008) Lung Epithelial Apoptosis in Influenza Virus Pneumonia: The Role of Macrophage-Expressed TNF-Related Apoptosis-Inducing Ligand. Journal of Experimental Medicine, 205, 3065-3077. https://doi.org/10.1084/jem.20080201

[62] Rodrigue-Gervais, I.G., Labbe, K., Dagenais, M., Dupaul-Chicoine, J., Champagne, C., Morizot, A., et al. (2014) Cellular Inhibitor of Apoptosis Protein cIAP2 Protects against Pulmonary Tissue Necrosis during Influenza Virus Infection to Promote Host Survival. Cell Host \& Microbe, 15, 23-35.

https://doi.org/10.1016/j.chom.2013.12.003

[63] Zhao, J., Zhao, J. and Perlman, S. (2010) T Cell Responses Are Required for Protection from Clinical Disease and for Virus Clearance in Severe Acute Respiratory Syndrome Coronavirus-Infected Mice. Journal of Virology, 84, 9318-9325. https://doi.org/10.1128/JVI.01049-10

[64] Fisman, D.N. (2000) Hemophagocytic Syndromes and Infection. Emerging Infectious Diseases, 6, 601-608.

[65] Mehta, P., McAuley, D.F., Brown, M., Sanchez, E., Tattersall, R.S., Manson, J.J., et al. (2020) COVID-19: Consider Cytokine Storm Syndromes and Immunosuppression. Lancet, 395, 1033-1034. https://doi.org/10.1016/S0140-6736(20)30628-0

[66] Ruan, Q., Yang, K., Wang, W., Jiang, L. and Song, J. (2020) Clinical Predictors of Mortality Due to COVID-19 Based on an Analysis of Data of 150 Patients from Wuhan, China. Intensive Care Medicine, 46, 846-848. https://doi.org/10.1007/s00134-020-05991-x

[67] Chen, J., Lau, Y.F., Lamirande, E.W., Paddock, C.D., Bartlett, J.H., Zaki, S.R., et al. (2010) Cellular Immune Responses to Severe Acute Respiratory Syndrome Corona- 
virus (SARS-CoV) Infection in Senescent BALB/c Mice: $\mathrm{CD}^{+} \mathrm{T}$ Cells Are Important in Control of SARS-CoV Infection. Journal of Virology, 84, 1289-1301. https://doi.org/10.1128/JVI.01281-09

[68] Li, X., Geng, M., Peng, Y., Meng, L. and Lu, S. (2020) Molecular Immune Pathogenesis and Diagnosis of COVID-19. Journal of Pharmaceutical Analysis, 10, 102-108. https://doi.org/10.1016/j.jpha.2020.03.001

[69] Tisoncik, J.R., Korth, M.J., Simmons, C.P., Farrar, J., Martin, T.R. and Katze, M.G. (2012) Into the Eye of the Cytokine Storm. Microbiology and Molecular Biology Reviews, 76, 16-32. https://doi.org/10.1128/MMBR.05015-11

[70] Yang, Y., Shen, C., Li, J., Yuan, J., Yang, M., Wang, F., et al. (2020) Exuberant Elevation of IP-10, MCP-3 and IL-1ra during SARS-CoV-2 Infection Is Associated with Disease Severity and Fatal Outcome. medRxiv. https://doi.org/10.1101/2020.03.02.20029975

[71] Huang, C., Wang, Y., Li, X., Ren, L., Zhao, J., Hu, Y., et al. (2020) Clinical Features of Patients Infected with 2019 Novel Coronavirus in Wuhan, China. Lancet, 395, 497-506. https://doi.org/10.1016/S0140-6736(20)30183-5

[72] Henry, B.M., de Oliveira, M.H.S., Benoit, S., Plebani, M. and Lippi, G. (2020) Hematologic, Biochemical and Immune Biomarker Abnormalities Associated with Severe Illness and Mortality in Coronavirus Disease 2019 (COVID-19): A Meta-Analysis. Clinical Chemistry and Laboratory Medicine, 58, 1021-1028. https://doi.org/10.1515/cclm-2020-0369

[73] Assiri, A., Al-Tawfiq, J.A., Al-Rabeeah, A.A., Al-Rabiah, F.A., Al-Hajjar, S,. AlBarrak, A., et al. (2013) Epidemiological, Demographic, and Clinical Characteristics of 47 Cases of Middle East Respiratory Syndrome Coronavirus Disease from Saudi Arabia: A Descriptive Study. The Lancet Infectious Diseases, 13, 752-761. https://doi.org/10.1016/S1473-3099(13)70204-4

[74] Weiskopf, D., Weinberger, B. and Grubeck-Loebenstein, B. (2009) The Aging of the Immune System. Transplant International, 22, 1041-1050. https://doi.org/10.1111/j.1432-2277.2009.00927.x

[75] Baas, T., Roberts, A., Teal, T.H., Vogel, L., Chen, J., Tumpey, T.M., et al. (2008) Genomic Analysis Reveals Age-Dependent Innate Immune Responses to Severe Acute Respiratory Syndrome Coronavirus. Journal of Virology, 82, 9465-9476. https://doi.org/10.1128/JVI.00489-08

[76] Channappanavar, R. and Perlman, S. (2017) Pathogenic Human Coronavirus Infections: Causes and Consequences of Cytokine Storm and Immunopathology. Seminars in Immunopathology, 39, 529-539. https://doi.org/10.1007/s00281-017-0629-X

[77] Chen, N., Zhou, M., Dong, X., Qu, J., Gong, F., Han, Y., et al. (2020) Epidemiological and Clinical Characteristics of 99 Cases of 2019 Novel Coronavirus Pneumonia in Wuhan, China: A Descriptive Study. Lancet, 395, 507-513. https://doi.org/10.1016/S0140-6736(20)30211-7

[78] Fu, L., Wang, B., Yuan, T., Chen, X., Ao, Y., Fitzpatrick, T., et al. (2020) Clinical Characteristics of Coronavirus Disease 2019 (COVID-19) in China: A Systematic Review and Meta-Analysis. Journal of Infection, 80, 656-665. https://doi.org/10.1016/j.jinf.2020.03.041

[79] Lauer, S.A., Grantz, K.H., Bi, Q., Jones, F.K., Zheng, Q., Meredith, H.R., et al. (2020) The Incubation Period of Coronavirus Disease 2019 (COVID-19) from Publicly Reported Confirmed Cases: Estimation and Application. Annals of Internal Medicine, 172, 577-582. https://doi.org/10.7326/M20-0504

[80] Cheng, Y., Luo, R., Wang, K., Zhang, M., Wang, Z., Dong, L., et al. (2020) Kidney 
Disease Is Associated with In-Hospital Death of Patients with COVID-19. Kidney International, 97, 829-838. https://doi.org/10.1016/j.kint.2020.03.005

[81] Guo, T., Fan, Y., Chen, M., Wu, X., Zhang, L., He, T., et al. (2020) Cardiovascular Implications of Fatal Outcomes of Patients with Coronavirus Disease 2019 (COVID19). JAMA Cardiology, 5, 811-818. https://doi.org/10.1001/jamacardio.2020.1017

[82] Shi, S., Qin, M., Shen, B., Cai, Y., Liu, T., Yang, F., et al. (2020) Association of Cardiac Injury with Mortality in Hospitalized Patients With COVID-19 in Wuhan, China. JAMA Cardiology, 5, 802-810. https://doi.org/10.1001/jamacardio.2020.0950

[83] Zhou, F., Yu, T., Du, R., Fan, G., Liu, Y., Liu, Z., et al. (2020) Clinical Course and Risk Factors for Mortality of Adult Inpatients with COVID-19 in Wuhan, China: A Retrospective Cohort Study. Lancet, 395, 1054-1062. https://doi.org/10.1016/S0140-6736(20)30566-3

[84] Nicholls, J.M., Poon, L.L., Lee, K.C., Ng, W.F., Lai, S.T., Leung, C.Y., et al. (2003) Lung Pathology of Fatal Severe Acute Respiratory Syndrome. Lancet, 361, 1773 1778. https://doi.org/10.1016/S0140-6736(03)13413-7

[85] Peiris, J.S., Guan, Y. and Yuen, K.Y. (2004) Severe Acute Respiratory Syndrome. Nature Medicine, 10, S88-S97. https://doi.org/10.1038/nm1143

[86] Gu, J., Gong, E., Zhang, B., Zheng, J., Gao, Z., Zhong, Y., et al. (2005) Multiple Organ Infection and the Pathogenesis of SARS. Journal of Experimental Medicine, 202, 415-424. https://doi.org/10.1084/jem.20050828

[87] Hwang, D.M., Chamberlain, D.W., Poutanen, S.M., Low, D.E., Asa, S.L. and Butany, J. (2005) Pulmonary Pathology of Severe Acute Respiratory Syndrome in Toronto. Modern Pathology, 18, 1-10. https://doi.org/10.1038/modpathol.3800247

[88] Qin, C., Zhou, L., Hu, Z., Zhang, S., Yang, S., Tao, Y., et al. (2020) Dysregulation of Immune Response in Patients with COVID-19 in Wuhan, China. Clinical Infectious Diseases, 71, 762-768. https://doi.org/10.1093/cid/ciaa248

[89] Belkaid, Y. and Rouse, B.T. (2005) Natural Regulatory T Cells in Infectious Disease. Nature Immunology, 6, 353-360. https://doi.org/10.1038/ni1181

[90] Imai, Y., Kuba, K., Rao, S., Huan, Y., Guo, F., Guan, B., et al. (2005) AngiotensinConverting Enzyme 2 Protects from Severe Acute Lung Failure. Nature, 436, 112-116. https://doi.org/10.1038/nature03712

[91] Lambert, D.W., Yarski, M., Warner, F.J., Thornhill, P., Parkin, E.T., Smith, A.I., et al. (2005) Tumor Necrosis Factor-Alpha Convertase (ADAM17) Mediates Regulated Ectodomain Shedding of the Severe-Acute Respiratory Syndrome-Coronavirus (SARS-CoV) Receptor, Angiotensin-Converting Enzyme-2 (ACE2). Journal of Biological Chemistry, 280, 30113-301199. https://doi.org/10.1074/jbc.M505111200

[92] Zou, Z., Yan, Y., Shu, Y., Gao, R., Sun, Y., Li, X., et al. (2014) Angiotensin-Converting Enzyme 2 Protects from Lethal Avian Influenza A H5N1 Infections. Nature Communications, 5, Article No. 3594. https://doi.org/10.1038/ncomms4594

[93] Monteil, V., Kwon, H., Prado, P., Hagelkruys, A., Wimmer, R.A., Stahl, M., et al. (2020) Inhibition of SARS-CoV-2 Infections in Engineered Human Tissues Using Clinical-Grade Soluble Human ACE2. Cell, 181, 905-913.e7. https://doi.org/10.1016/j.cell.2020.04.004

[94] Arentz, M., Yim, E., Klaff, L., Lokhandwala, S., Riedo, F., Chong, M., et al. (2020) Characteristics and Outcomes of 21 Critically Ill Patients with COVID-19 in Washington State. JAMA, 323, 1612-1614. https://doi.org/10.1001/jama.2020.4326

[95] Inciardi, R.M., Lupi, L., Zaccone, G., Italia, L., Raffo, M., Tomasoni, D., et al. (2020) Cardiac Involvement in a Patient with Coronavirus Disease 2019 (COVID-19). JAMA 
Cardiology, 5, 189-824. https://doi.org/10.1001/jamacardio.2020.1096

[96] Lippi, G., Lavie, C.J. and Sanchis-Gomar, F. (2020) Cardiac Troponin I in Patients with Coronavirus Disease 2019 (COVID-19): Evidence from a Meta-Analysis. Progress in Cardiovascular Diseases, 63, 390-391. https://doi.org/10.1016/j.pcad.2020.03.001

[97] Crackower, M.A., Sarao, R., Oudit, G.Y., Yagil, C., Kozieradzki, I., Scanga, S.E., et al. (2002) Angiotensin-Converting Enzyme 2 Is an Essential Regulator of Heart Function. Nature, 417, 822-828. https://doi.org/10.1038/nature00786

[98] Oudit, G.Y., Kassiri, Z., Jiang, C., Liu, P.P., Poutanen, S.M., Penninger, J.M., et al. (2009) SARS-Coronavirus Modulation of Myocardial ACE2 Expression and Inflammation in Patients with SARS. European Journal of Clinical Investigation, 39, 618-625. https://doi.org/10.1111/j.1365-2362.2009.02153.x

[99] Ding, Y., Wang, H., Shen, H., Li, Z., Geng, J., Han, H., et al. (2003) The Clinical Pathology of Severe Acute Respiratory Syndrome (SARS): A Report from China. The Journal of Pathology, 200, 282-289. https://doi.org/10.1002/path.1440

[100] Natanson, C., Eichenholz, P.W., Danner, R.L., Eichacker, P.Q., Hoffman, W.D., Kuo, G.C., et al. (1989) Endotoxin and Tumor Necrosis Factor Challenges in Dogs Simulate the Cardiovascular Profile of Human Septic Shock. Journal of Experimental Medicine, 169, 823-832. https://doi.org/10.1084/jem.169.3.823

[101] Pathan, N., Hemingway, C.A., Alizadeh, A.A., Stephens, A.C., Boldrick, J.C., Oragui, E.E., et al. (2004) Role of Interleukin 6 in Myocardial Dysfunction of Meningococcal Septic Shock. Lancet, 363, 203-209. https://doi.org/10.1016/S0140-6736(03)15326-3

[102] Stanzani, G., Duchen, M.R. and Singer, M. (2019) The Role of Mitochondria in Sepsis-Induced Cardiomyopathy. Biochimica et Biophysica Acta (BBA)-Molecular Basis of Disease, 1865, 759-773. https://doi.org/10.1016/j.bbadis.2018.10.011

[103] Epelman, S., Tang, W.H., Chen, S.Y., Van Lente, F., Francis, G.S. and Sen, S. (2008) Detection of Soluble, Angiotensin-Converting Enzyme 2 in Heart Failure: Insights into the Endogenous Counter-Regulatory Pathway of the Renin-Angiotensin-Aldosterone System. Journal of the American College of Cardiology, 52, 750-744. https://doi.org/10.1016/j.jacc.2008.02.088

[104] Rutschow, S., Li, J., Schultheiss, H.P. and Pauschinger, M. (2006) Myocardial Proteases and Matrix Remodeling in Inflammatory Heart Disease. Cardiovascular Research, 69, 646-656. https://doi.org/10.1016/j.cardiores.2005.12.009

[105] Chen, L., Li, X., Chen, M., Feng, Y. and Xiong, C. (2020) The ACE2 Expression in Human Heart Indicates New Potential Mechanism of Heart Injury among Patients Infected with SARS-CoV-2. Cardiovascular Research, 116, 1097-1100. https://doi.org/10.1093/cvr/cvaa078

[106] Thomas, M.C., Pickering, R.J., Tsorotes, D., Koitka, A., Sheehy, K., Bernardi, S., et al. (2010) Genetic Ace2 Deficiency Accentuates Vascular Inflammation and Atherosclerosis in the ApoE Knockout Mouse. Circulation Research, 107, 888-897. https://doi.org/10.1161/CIRCRESAHA.110.219279

[107] Wang, K., Gheblawi, M. and Oudit, G.Y. (2020) Angiotensin Converting Enzyme 2: A Double-Edged Sword. Circulation, 142, 426-428. https://doi.org/10.1161/CIRCULATIONAHA.120.047049

[108] Corrales-Medina, V.F., Alvarez, K.N., Weissfeld, L.A., Angus, D.C., Chirinos, J.A., Chang, C.C., et al. (2015) Association between Hospitalization for Pneumonia and Subsequent Risk of Cardiovascular Disease. JAMA, 313, 264-274. https://doi.org/10.1001/jama.2014.18229 
[109] Violi, F., Cangemi, R. and Calvieri, C. (2014) Pneumonia, Thrombosis and Vascular Disease. Journal of Thrombosis and Haemostasis, 12, 1391-1400. https://doi.org/10.1111/jth.12646

[110] Mogensen, T.H. (2009) Pathogen Recognition and Inflammatory Signaling in Innate Immune Defenses. Clinical Microbiology Reviews, 22, 240-273. https://doi.org/10.1128/CMR.00046-08

[111] Vallance, P., Collier, J. and Bhagat, K. (1997) Infection, Inflammation, and Infarction: Does Acute Endothelial Dysfunction Provide a Link? Lancet, 349, 1391-1392. https://doi.org/10.1016/S0140-6736(96)09424-X

[112] Libby, P. and Simon, D.I. (2001) Inflammation and Thrombosis: The Clot Thickens. Circulation, 103, 1718-1720. https://doi.org/10.1161/01.CIR.103.13.1718

[113] Li, Z., Wu, M., Yao, J., Guo, J., Liao X, Song S, et al. (2020) Caution on Kidney Dysfunctions of COVID-19 Patients. medRxiv. https://doi.org/10.1101/2020.02.08.20021212

[114] Chu, K.H., Tsang, W.K., Tang, C.S., Lam, M.F., Lai, F.M., To, K.F., et al. (2005) Acute Renal Impairment in Coronavirus-Associated Severe Acute Respiratory Syndrome. Kidney International, 67, 698-705. https://doi.org/10.1111/j.1523-1755.2005.67130.x

[115] Batlle, D., Soler, M.J., Sparks, M.A., Hiremath, S., South, A.M., Welling, P.A., et al. (2020) Acute Kidney Injury in COVID-19: Emerging Evidence of a Distinct Pathophysiology. Journal of the American Society of Nephrology, 31, 1380-1383. https://doi.org/10.1681/ASN.2020040419

[116] Su, H., Yang, M., Wan, C., Yi, L.X., Tang, F., Zhu, H.Y., et al. (2020) Renal Histopathological Analysis of 26 Postmortem Findings of Patients with COVID-19 in China. Kidney International, 98, 219-227. https://doi.org/10.1016/j.kint.2020.04.003

[117] Hamming, I., Timens, W., Bulthuis, M.L., Lely, A.T., Navis, G. and van Goor, H. (2004) Tissue Distribution of ACE2 Protein, the Functional Receptor for SARS Coronavirus. A First Step in Understanding SARS Pathogenesis. The Journal of Pathology, 203, 631-637. https://doi.org/10.1002/path.1570

[118] Li, J., Li, R.J., Lv, G.Y. and Liu, H.Q. (2015) The Mechanisms and Strategies to Protect from Hepatic Ischemia-Reperfusion Injury. European Review for Medical and Pharmacological Sciences, 19, 2036-2047.

[119] Li, L., Li, S., Xu, M., Yu, P., Zheng, S., Duan, Z., et al. (2020) Risk Factors Related to Hepatic Injury in Patients with Corona Virus Disease 2019. medRxiv. https://doi.org/10.1101/2020.02.28.20028514

[120] Tian, S., Xiong, Y., Liu, H., Niu, L., Guo, J., Liao, M., et al. (2020) Pathological Study of the 2019 Novel Coronavirus Disease (COVID-19) through Postmortem Core Biopsies. Modern Pathology, 33, 1007-1014. https://doi.org/10.1038/s41379-020-0536-x

[121] Levi, M., van der Poll, T., ten Cate, H. and van Deventer, S.J. (1997) The Cytokine-Mediated Imbalance between Coagulant and Anticoagulant Mechanisms in Sepsis and Endotoxaemia. European Journal of Clinical Investigation, 27, 3-9. https://doi.org/10.1046/j.1365-2362.1997.570614.x

[122] Page, M.J., Bester, J. and Pretorius, E. (2018) The Inflammatory Effects of TNF- $\alpha$ and Complement Component 3 on Coagulation. Scientific Reports, 8, Article No, 1812. https://doi.org/10.1038/s41598-018-20220-8

[123] Herbert, J.M., Savi, P., Laplace, M.C. and Lale, A. (1992) IL-4 Inhibits LPS-, IL-1 $\beta$ and TNF $\alpha$-Induced Expression of Tissue Factor in Endothelial Cells and Monocytes. FEBS Letters, 310, 31-33. https://doi.org/10.1016/0014-5793(92)81139-D 
[124] van der Poll, T., Buller, H.R., ten Cate, H., Wortel, C.H., Bauer, K.A., van Deventer, S.J., et al. (1990) Activation of Coagulation after Administration of Tumor Necrosis Factor to Normal Subjects. New England Journal of Medicine, 322, 1622-1167. https://doi.org/10.1056/NEJM199006073222302

[125] Cox, D., Kerrigan, S.W. and Watson, S.P. (2011) Platelets and the Innate Immune System: Mechanisms of Bacterial-Induced Platelet Activation. Journal of Thrombosis and Haemostasis, 9, 1097-1107. https://doi.org/10.1111/j.1538-7836.2011.04264.x

[126] Nencioni, A., Trzeciak, S. and Shapiro, N.I. (2009) The Microcirculation as a Diagnostic and Therapeutic Target in Sepsis. Internal and Emergency Medicine, 4, 413418. https://doi.org/10.1007/s11739-009-0297-5

[127] Boisrame-Helms, J., Kremer, H., Schini-Kerth, V. and Meziani, F. (2013) Endothelial Dysfunction in Sepsis. Current Vascular Pharmacology, 11, 150-160. https://doi.org/10.2174/157016113805290317

[128] Tsai, L.K., Hsieh, S.T. and Chang, Y.C. (2005) Neurological Manifestations in Severe Acute Respiratory Syndrome. Acta Neurologica Taiwanica, 14, 113-119.

[129] Mizuguchi, M., Yamanouchi, H., Ichiyama, T. and Shiomi, M. (2007) Acute Encephalopathy Associated with Influenza and Other Viral Infections. Acta Neurologica Scandinavica. Supplementum, 115, 45-56. https://doi.org/10.1111/j.1600-0404.2007.00809.x

[130] Kim, J.E., Heo, J.H., Kim, H.O., Song, S.H., Park, S.S., Park, T.H., et al. (2017) Neurological Complications during Treatment of Middle East Respiratory Syndrome. Journal of Clinical Neurology, 13, 227-233. https://doi.org/10.3988/jicn.2017.13.3.227

[131] Arbour, N., Day, R., Newcombe, J. and Talbot, P.J. (2000) Neuroinvasion by Human Respiratory Coronaviruses. Journal of Virology, 74, 8913-8921. https://doi.org/10.1128/JVI.74.19.8913-8921.2000

[132] Murray, R.S., Brown, B., Brian, D. and Cabirac, G.F. (1992) Detection of Coronavirus RNA and Antigen in Multiple Sclerosis Brain. Annals of Neurology, 31, 525-533. https://doi.org/10.1002/ana.410310511

[133] Cristallo, A., Gambaro, F., Biamonti, G., Ferrante, P., Battaglia, M. and Cereda, P.M. (1997) Human Coronavirus Polyadenylated RNA Sequences in Cerebrospinal Fluid from Multiple Sclerosis Patients. New Microbiologica, 20, 105-114.

[134] Gutierrez-Ortiz, C., Mendez-Guerrero, A., Rodrigo-Rey, S., San Pedro-Murillo, E., Bermejo-Guerrero, L., Gordo-Manas, R., et al. (2020) Miller Fisher Syndrome and Polyneuritis Cranialis in COVID-19. Neurology, 95, e601-e605. https://doi.org/10.1212/WNL.0000000000009619

[135] Mao, L., Jin, H., Wang, M., Hu, Y., Chen, S., He, Q., et al. (2020) Neurologic Manifestations of Hospitalized Patients with Coronavirus Disease 2019 in Wuhan, China. JAMA Neurology, 77, 683-690. https://doi.org/10.1001/jamaneurol.2020.1127

[136] Giacomelli, A., Pezzati, L., Conti, F., Bernacchia, D., Siano, M., Oreni, L., et al. (2020) Self-Reported Olfactory and Taste Disorders in Patients with Severe Acute Respiratory Coronavirus 2 Infection: A Cross-Sectional Study. Clinical Infectious Diseases, 71, 889-980. https://doi.org/10.1093/cid/ciaa330

[137] Guo, Y.R., Cao, Q.D., Hong, Z.S., Tan, Y.Y., Chen, S.D., Jin, H.J., et al. (2020) The Origin, Transmission and Clinical Therapies on Coronavirus Disease 2019 (COVID-

19) Outbreak-An Update on the Status. Military Medical Research, 7, Article No. 11. https://doi.org/10.1186/s40779-020-00240-0

[138] Baig, A.M. and Sanders, E.C. (2020) Potential Neuroinvasive Pathways of SARSCoV-2: Deciphering the Spectrum of Neurological Deficit Seen in Coronavirus Dis- 
ease-2019 (COVID-19). Journal of Medical Virology, 92, 1845-1857. https://doi.org/10.1002/jmv.26105

[139] Li, Y., Fu, L., Gonzales, D.M. and Lavi, E. (2004) Coronavirus Neurovirulence Correlates with the Ability of the Virus to Induce Proinflammatory Cytokine Signals from Astrocytes and Microglia. Journal of Virology, 78, 3398-3406. https://doi.org/10.1128/JVI.78.7.3398-3406.2004

[140] Chen, C., Zhang, X.R., Ju, Z.Y. and He, W.F. (2020) Advances in the Research of Mechanism and Related Immunotherapy on the Cytokine Storm Induced by Coronavirus Disease 2019. Chinese Journal of Burns, 36, 471-475.

[141] Sankowski, R., Mader, S. and Valdes-Ferrer, S.I. (2015) Systemic Inflammation and the Brain: Novel Roles of Genetic, Molecular, and Environmental Cues as Drivers of Neurodegeneration. Frontiers in Cellular Neuroscience, 9, Article No. 28. https://doi.org/10.3389/fncel.2015.00028

[142] Desforges, M., Le Coupanec, A., Dubeau, P., Bourgouin, A., Lajoie, L., Dube, M., et al. (2019) Human Coronaviruses and Other Respiratory Viruses: Underestimated Opportunistic Pathogens of the Central Nervous System? Viruses, 12, Article No. 14. https://doi.org/10.3390/v12010014

[143] Baig, A.M., Khaleeq, A., Ali, U. and Syeda, H. (2020) Evidence of the COVID-19 Virus Targeting the CNS: Tissue Distribution, Host-Virus Interaction, and Proposed Neurotropic Mechanisms. ACS Chemical Neuroscience, 11, 995-998. https://doi.org/10.1021/acschemneuro.0c00122

[144] McAbee, G.N., Brosgol, Y., Pavlakis, S., Agha, R. and Gaffoor, M. (2020) Encephalitis Associated with COVID-19 Infection in an 11-Year-Old Child. Pediatric Neurology, 109, 94. https://doi.org/10.1016/j.pediatrneurol.2020.04.013

[145] Li, Y.C., Bai, W.Z. and Hashikawa, T. (2020) The Neuroinvasive Potential of SARSCoV2 May Play a Role in the Respiratory Failure of COVID-19 Patients. Journal of Medical Virology, 92, 552-555. https://doi.org/10.1002/jmv.25728

[146] Butowt, R. and Bilinska, K. (2020) SARS-CoV-2: Olfaction, Brain Infection, and the Urgent Need for Clinical Samples Allowing Earlier Virus Detection. ACS Chemical Neuroscience, 11, 1200-1203. https://doi.org/10.1021/acschemneuro.0c00172

[147] Perlman, S., Evans, G. and Afifi, A. (1990) Effect of Olfactory Bulb Ablation on Spread of a Neurotropic Coronavirus into the Mouse Brain. Journal of Experimental Medicine, 172, 1127-1132. https://doi.org/10.1084/jem.172.4.1127

[148] Netland, J., Meyerholz, D.K., Moore, S., Cassell, M. and Perlman, S. (2008) Severe Acute Respiratory Syndrome Coronavirus Infection Causes Neuronal Death in the Absence of Encephalitis in Mice Transgenic for Human ACE2. Journal of Virology, 82, 7264-7275. https://doi.org/10.1128/JVI.00737-08

[149] Li, Y.C., Bai, W.Z., Hirano, N., Hayashida, T., Taniguchi, T., Sugita, Y., et al. (2013) Neurotropic Virus Tracing Suggests a Membranous-Coating-Mediated Mechanism for Transsynaptic Communication. Journal of Comparative Neurology, 521, 203-312. https://doi.org/10.1002/cne.23171

[150] Moriguchi, T., Harii, N., Goto, J., Harada, D., Sugawara, H., Takamino, J., et al. (2020) A First Case of Meningitis/Encephalitis Associated with SARS-Coronavirus-2. International Journal of Infectious Diseases, 94, 55-58. https://doi.org/10.1016/j.ijid.2020.03.062

[151] Domingues, R.B., Mendes-Correa, M.C., de Moura Leite, F.B.V., Sabino, E.C., Salarini, D.Z., Claro, I., et al. (2020) First Case of SARS-COV-2 Sequencing in Cerebrospinal Fluid of a Patient with Suspected Demyelinating Disease. Journal of Neurology, 267, 3154-3156. https://doi.org/10.1007/s00415-020-09996-w 
[152] Bonetti, P.O., Lerman, L.O. and Lerman, A. (2003) Endothelial Dysfunction: A Marker of Atherosclerotic Risk. Arteriosclerosis, Thrombosis, and Vascular Biology, 23, 168-175. https://doi.org/10.1161/01.ATV.0000051384.43104.FC

[153] Paniz-Mondolfi, A., Bryce, C., Grimes, Z., Gordon, R.E., Reidy, J., Lednicky, J., et al. (2020) Central Nervous System Involvement by Severe Acute Respiratory Syndrome Coronavirus-2 (SARS-CoV-2). Journal of Medical Virology, 92, 699-702. https://doi.org/10.1002/jmv.25915

[154] McCray Jr., P.B., Pewe, L., Wohlford-Lenane, C., Hickey, M., Manzel, L., Shi, L., et al. (2007) Lethal Infection of K18-hACE2 Mice Infected with Severe Acute Respiratory Syndrome Coronavirus. Journal of Virology, 81, 813-821. https://doi.org/10.1128/JVI.02012-06

[155] Xia, H. and Lazartigues, E. (2010) Angiotensin-Converting Enzyme 2: Central Regulator for Cardiovascular Function. Current Hypertension Reports, 12, 170-175. https://doi.org/10.1007/s11906-010-0105-7

[156] Glowacka, I., Bertram, S., Herzog, P., Pfefferle, S., Steffen, I., Muench, M.O., et al. (2010) Differential Downregulation of ACE2 by the Spike Proteins of Severe Acute Respiratory Syndrome Coronavirus and Human Coronavirus NL63. Journal of Virology, 84, 1198-1205. https://doi.org/10.1128/JVI.01248-09

[157] Abdennour, L., Zeghal, C., Deme, M. and Puybasset, L. (2012) Interaction BrainLungs. Annales Françaises d’ Anesthésie et de Réanimation, 31, e101-e107. https://doi.org/10.1016/j.annfar.2012.04.013

[158] Terrence, C.F., Rao, G.R. and Perper, J.A. (1981) Neurogenic Pulmonary Edema in Unexpected, Unexplained Death of Epileptic Patients. Annals of Neurology, 9, 458464. https://doi.org/10.1002/ana.410090508

[159] Sedy, J., Kunes, J. and Zicha, J. (2015) Pathogenetic Mechanisms of Neurogenic Pulmonary Edema. Journal of Neurotrauma, 32, 1135-1145. https://doi.org/10.1089/neu.2014.3609

[160] Wang, Y., Wang, Y., Chen, Y. and Qin, Q. (2020) Unique Epidemiological and Clinical Features of the Emerging 2019 Novel Coronavirus Pneumonia (COVID-19) Implicate Special Control Measures. Journal of Medical Virology, 92, 568-576. https://doi.org/10.1002/jmv.25748

[161] Li, Y., Li, M., Wang, M., Zhou, Y., Chang, J., Xian, Y., et al. (2020) Acute Cerebrovascular Disease Following COVID-19: A Single Center, Retrospective, Observational Study. Stroke and Vascular Neurology, 5, 279-284.

https://doi.org/10.1136/svn-2020-000431 